\title{
The Local Wisdom of Tunggu Tubang Culture in the Challenges of the Times (Study on Ethnical Semende District Muara Enim South Sumatera)
}

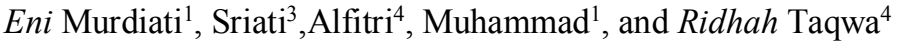 \\ ${ }^{1}$ Department of Environmental Science, Graduate Program-Universitas Sriwijaya, \\ Palembang, Indonesia \\ ${ }^{2}$ Preaching and Communication Faculty, Islamic State University of Raden Fatah, \\ Palembang,Indonesia \\ ${ }^{3}$ Department of Agribusiness, Faculty of Agriculture, Universitas Sriwijaya, Palembang, \\ Indonesia ${ }^{4}$ Department of Sociology, Faculty of Social and Politic, Universitas Sriwijaya, \\ Palembang, Indonesia
}

\begin{abstract}
This study discusses the local wisdom of TungguTubang culture that is still embraced by the Semende ethnic community in MuaraEnim district. This study uses a qualitative descriptive approach with more emphasis on TungguTubang study facing the challenges in the era of globalization and modernization. The uniqueness local wisdom of TungguTubang culture which initially harmony with the surrounding natural environment, finally experienced a drastic change. The result of the research shows that the high- value award given by a TungguTubang to Semende society is not the expected reward anymore, because of the internal and external change factor of the social causes a change in the meaning and value of TungguTubangitself.
\end{abstract}

\section{Introduction}

The issue of environmental crises, both in terms of management and conservation facing humans today, is increasingly very worrying. The loss of localwisdom cultural inherited by the ancestors for the following generations is due to various internal and external factors. The emergence of conflicts between families and communities in a culture area makes the tradition of deep-rooted customs increasingly shifting and extinct. Whereas it can not be denied, the existence of different characters and unique in addressing environmental problems are found in every area in Indonesia, one of which is the cultural tradition of TungguTubang on Semende ethnic Darat Tengah, DaratLaut and DaratUlu located in MuaraEnim regency, South Sumatera. Anthropologically, culture is formed by the presence of human beings who have the mind and the instinct to adapt to their environment [1]. Therefore, the local wisdom of TungguTubang cultural in Semende provides an overview of the eldest daughter in a family who takes care of the family and

\footnotetext{
*Corresponding author: eninurdiati@ymail.com
} 
organizes the environmental management of houses, ponds, gardens and rice fields for their extended family. Tunggu Tubang is the highest award given to girls to be able to assume full responsibility for family life. But the emergence of modernization and globalization in the life of people who still adhere to the tradition of Tunggu Tubang, will certainly get a big enough challenge. This is the study that will be discussed in this paper.

\section{Materials and Methods}

The qualitative descriptive research method used in this research. According to [2] "qualitative approach is a procedure of social, cultural and philosophical research which produces descriptive data in the form of words or notes related to meaning, value and meaning". Research data in the form of observations made and felt researchers and explore more in depth the events, activities, processes undertaken by the community. In-depth interviews with women TungguTubang and parents who understand and interpret the local wisdom of the ethnic Semende community culture. In addition, research on people who still maintain the tradition of Tunggu Tubang in Semende (Darat Tengah, Daratlaut, and Darat Ulu). Informant research using purposive sampling technique, that is sampling based on certain considerations [3]. The criteria for selection of informants is also based on the age of at least 30 years and a maximum of 65 years by knowing the ins and outs of Tunggu Tubang, and willing as a research informant. After that, the data analysis technique is done interactively and continuously to the study of TungguTubang in the challenges of the times to finish.

\section{Results and Discussions}

Geographically the position of Muara Enim Regency has located between $4^{\circ}$ to $6^{\circ}$ South Latitude and $104^{\circ}$ to $106^{\circ}$ East Longitude. Muara Enim Regency is an agrarian area with an area of $7.483 .06 \mathrm{~km}^{2}$, consisting of 20 districts. The diversity of topographic condition of the region with the high lands in the south west is a series of Bukit Barisan mountains, which include Semende Darat Tengah, Darat Laut, Darat Ulu, and Tanjung Agung Subdistrict. Several villages in the sub-district of Semende Darat Tengah, Semende Darat Laut, and Semende Darat Ulu have adequate educational facilities. There are educational institutions of kindergarten, elementary, and high school level.

The economy of Semende society is mostly in agriculture, although the land that is owned is ulayat land. Land tenure rights (hakulayat) owned by their ancestors over customary law prevailing within the Semende community. Livelihoods other than rice fields, Semende community also has a fish pond and coffee farming. The story of Ethnic Semende comes from several sections and important notes of the Semende Ethnic Tradition Institute. Semende is a settlement land located in Talang Tumutan Tujuh (Beginning of Semende's central area), where around 1650 AD or $1072 \mathrm{H}$, SyechNurqadim AlBaharuddin/Puyang. The crew and the famous religious big family in Islam are the first to open the land. TalangTumutanTujuh is also known as the village of Para Dipe / Pardipe (The Adulterers of Religion) by Semende community [4].

The eldest married daughter is placed in the highest position against power over home and agricultural land that is based on Islamic teachings. Understanding TungguTubang has the meaning of the word "Wait" and "Tubang". Wait word interpreted by waiting. Tubang in Semende is a piece of bamboo that serves as a tool for storing kitchen spices. Kitchen discourse gives an idea that women are considered capable of taking care of the family well and give loving attention. Furthermore, TungguTubang given understanding someone who 
can bear all the responsibilities, whether light or heavy. In the Semende ethnic community which adheres to the matrilineal line with the TungguTubang tradition, it is still a recognized symbol and status. Women's identity in their social status which has value is very valuable. Society places women not merely symbols, butis a noble essence that marks the degree and dignity of a family [5-7].

The Indigenous Tunggu Tubang for ethnic Semende has a customs where the eldest daughter who obtained an inheritance in the form of house and agricultural land (property that can not be traded). The full accountability of the eldest daughter to the lives of parents, and their brothers to adulthood and self-reliant family [8]. The context of power Tunggu Tubang that is closely related to the environment is illustrated by the following things:

- The old house/traditional house owned by Tunggu Tubang from the previous generation must be maintained, cared for Tunggu Tubang house is in the form of a house on stilts, and made of wood originating from a customary forest. A house built, not just a house to livein. The house is the supreme

- possession of Tunggu Tubang. The old house/custom house is made with the process of nyeram (prayer) led by the pendite or juraitue, a prayer addressed to the God Mule Jadi and the God Rimbe Raye. A drinking event was held, then wearing incense and flowers and offerings placed on bongkot/base of the wooden stem given the instruction of the pendite. The ceremony is over, logging begins to build a house. Building a house is done by Bebie (mutual cooperation).

- In the field of agriculture/paddy fields is done on the land not far from the settlement. Tunggu Tubang to work on, maintain and make productive fields. Tunggu Tubang should have knowledge on how to get the results from the paddy fields, Surely they must understand when to plant, harvest and use the harvest for their extended family. Opening the farm or paddy fields done with a rattle. The offerings are placed in the four corners of paddy fields and Punjung (in the form of food) placed in the middle of paddy fields. On every full moon of Punjung offerings should always be held to avoid pests of diseases, disasters and get abundant results.

- Gardening activity/ghepangan with coffee plants they do in the traditional forest, which has existed since the Dutch colonial era. Coffee garden/kawe after exhausted nyake (exhausted 8 or 9 years of harvest) will be used as rice fields. Opening the rice field from the former gardening done ritual that is almost not much different from the opening of agricultural land/ricefields.

- Pond/tebatis owned by Tunggu Tubang must be filled with enough fish for the needs of every day family members.

- The traditional tradition of Tunggu Tubang embodied in the ethos of ecocentrism, fully realizing that nature is a part that can not be separated from human life and has a harmony reciprocal relationship, thus creating a balanced ecosystem. The orientation of wisdom to the environment, making beliefs of the community's perspective on the TungguTubang custom which gives rise to the classification of meaning and role functions, either in the form of symbols, norms, rules, and values related to the environment of Semende community. TungguTubang has a very meaningful and valuable social class in Semende society, although the meaning for Tunggu Tubang is a very heavy burden, it can be seen from the lyrics of the song from Serunting Jaya (an ethnic Semende) who poured the story of Tunggu Tubang.

\section{Tunggu Tubang}

Tunggu Tubang Anak Betine (Female child)Tunggu Tubang Anak Betine (Female child) Sianu Anak Betine (She is the female child) 
Badah bekumpul ngah kebali'an (the place to gather and to go back)

Badah bekumpul ngah kebali'an (the place to gather and to go back)

Sianu kebali' an (she is regarded as the place back home)

Tunggu Tubang memang mak dek mak (Tunggu Tubang is silmuateneously happy and unhappy)

Sianu memang mak dek mak (She is silmuateneously happy and unhappy)

Banyaklah dek mak (more toward unhappiness)

Banyaklah dek mak (more toward unhappiness)

Tinggal lemaknye (Just leave her happiness)

Sianu tinggal lemaknya (She just leave her happiness)

Tunggu Tubang Anak Betine (Female Child) Sianu Anak Betine (She is a female child) Pait ngan manis, Asam ngan benyai (Bitter and Sweet, Sour and bland)

Tanggungan gale (becoming everyone's burden)

Sianu tanggungan gale (Everyone is under her responsibility)

Tunggu Tubang memang mak dek mak (Tunggu Tubang is silmuateneously happy and unhappy)

Sianu memang mak dek mak (She is silmutaneously happy and unhappy)

Pisuh pelejehupat ngah dawai (All problem are under her responsibility)

Ndikulam gale (All her resposibility)

Sianu ndikulam gale (She is responsible for all things)

Tunggu Tubang banyak cerite (Lots of stories about TungguTubang)

Suke dukenye, Sianu suke dukenye (Happiness and sadness, her happiness and sadness)

Tunggu Tubang memang mak dek mak (TungguTubang is silmuateneously happy and unhappy) Sianu memang mak dek mak (She is silmutaneously happy and unhappy)

Segale ase, segale ase bagian gale(All feelings belong toher)

Sianu bagian gale (She is a part of everything)

Tunggu Tubang Anak betine (Female child) Sianu Anak betine (She is a female child) Kereh lah hapat kepayah dikde (All her feelings must be taken toheart)

Diam bikade (Just take it)

Sianu diambikade (She would just take it) Tunggu Tubang memang mak dek mak (Tunggu Tubang is silmuateneously happy and unhappy)

Sianu memang mak dek mak (She is silmuateneously happy and unhappy)

Nggok matitulah (Until death) Nggok matitulah (Until death) Mangke berege (be appreciated)

Sianu mangke berege (She will still be appreciated)

Tunggu Tubang Anak Betine (Female child) Sianu Anak Betine (She is a Female child) Nyebusukmasam (Unpleasant smell) Ngecapnye pule (mocked)

Sianungecapnye pule (She is mocked)

Banyaklah dek mak (Lots of unhappiness)

Sianu tinggal lemaknye... (She just leave her happiness))

The lyrics songs are sung by Serunting Jaya, depicting the story of TungguTubang with grief and heavy burden on the family. Tunggu Tubang will get criticism if they make a mistake. Tunggu Tubang is a very valuable in the social position of society culture Semende. This value is still recognized by the Semende community, as the expression of value is a pattern of knowledge that means both good and bad functionally occur in the 
social conditions of society, which is used as a guide someone to act orbehave.

According to the elders or traditional leaders, Asma, 39 years old from Darat Ulu Semende (interview on May 16, 2017), the tradition of Tunggu Tubang is a customary law still held firmly until now. When parents die, the estate automatically becomes the property of the eldest daughter. If there is no daughter then the wife of the eldest son becomes Tunggu Tubang (Ngangkit). This matrilineal line binds tightly to a family. Tunggu Tubang is a picture of a big family place to gather and not get scattered. The love given by women comes from the teachings of Islam, must be run for the blessing of the Creator.

Then the phrase women of Tunggu Tubang Semende Darat Tengah, named Iyah, 50 years old and has the first daughter of the successor Tunggu Tubang. The life of Tunggu Tubang is very valuable in the eyes of the Semende community, taking care of large families with living parents and younger siblings to be schooled into their responsibilities, but this burden is not easy because of the conditions of agricultural land that are unable to meet the needs of large families. Iyah began to think what kind of Tunggu Tubang will be lived by her daughter someday. Life is more difficult than the life of her own mother. Thought Tunggu Tubang like Iyah, in the development of culture and application in life, also develop good and bad values and what she should do and not done for her generation later personal interview, June 18, 2017). In line with Yun from Darat Laut. A 60-year-old Tunggu Tubang, said their extended family experienced a conflict after the parents were gone. Distribution of crops and gardens that did not match the expectations of her brothers made one of her brothers wandering to Jakarta and did not meet until now (Interview, 13 July 2017).

The influence of education also affects the meaning of Tunggu Tubang itself, the 38year-old Hawah's expression (Darat Laut Semende) who works as a civil servant in Batu Raja City. Her high education puts her in a decent job. Hawah is better off releasing the Tunggu Tubang status mandated to her, because the workplace is far from the home of the parents. She hands over the status of Tunggu Tubang to her other siblings by providing her modest financial assistance to take care of the house, and the living parent. But she kept her routine back to his village to visit the big families (Interview, 11 March 2017).

The positive and negative impacts of technological progress greatly affect the local wisdom of the people of a region. Culture as a container from the perspective and knowledge of society to realize local wisdom to the environment slowly began to erode. In the era of modernization and globalization, internal and external changes so rapidly affect human life. Changes in social values and norms, patterns of organizational behavior, organizational structures, layers in society, power and authority, social interaction and so on[9].

Even this social change greatly affects the cultural customs of Tunggu Tubang. The role of Tunggu Tubang which is the local wisdom of Semende ethnic has slowly been shifting. As a Culture area, of the many Tunggu Tubang in the present day, Tunggu Tubang no longer positions their roles based on customs. As a Tunggu Tubang with a profession as a farmer with a tradition that is considered valuable or berege, does not promise a bright future for the future because in addition to heavy work ranging from tillage, maintenance to harvest. Tunggu Tubang must be able to meet the needs of the family and the social needs of the community. Yields from their agricultural fields are usually used up for daily meals, while events in the community tradition must be fulfilled, for example providing staples of rice, chicken and vegetables. Sometimes they have to owe to needs like this. If this is not done, they feel they will get criticism from the community because they are considered not the women of Tunggu Tubang who know their status and role. It can not be denied the symbols and meaning of TungguTubang change. The dynamics of life will always change. 
The context of individuals and communities living in an era of communication and sophisticated technology will influence social change that has an impact on interaction, social norms, community economics, marriage, education and other things. The order and function of society change to make traditions with values, management of the environment and functions and roles of individuals change internally and externally. Beside that as Tunggu Tubang, Formation and change of attitude is not always permanent. Interactions that occur in individual relationships, changing education, the influence of inter-ethnic marriage patterns, will be able to shape and change attitudes. with a marriage pattern that requires the Woman of Tunggu Tubang to remain in the house of her parents' inheritance. If they come out, they will no longer be Tunggu Tubang. The development of the times due to globalization and modernization made the Tunggu Tubang role not the same as before. Local culture slowly begins to erode. The community began to leave the TungguTubang culture because it was deemed irrelevant to the current state of development. Some changes caused by internal and external factors of society, amongothers:

- As a result of the increase of population with limited natural resources unable to meet the needs of family Tunggu Tubang, For example about the existence of conflicts over customary forests with the government that used to be the place for the community for coffee gardening. Forests do not work properly, disputes over forest benefits between government policy and local people continue to be the trigger of conflict that has a major impact on the Tunggu Tubang tradition. In reality coffee crops became a reliable commodity in the Muara Enim area, especially in the days of the VOC reign. In the highlands of Pasemah which includes several districts, such as Muara Enim, Lahat, and Empat Lawang are producers of robusta coffee. By 2015, from tens of thousands of hectares of coffee plantations are collected at 139.754 tons or equivalent to $30 \%$ of the total national coffee production. The high production capacity of South Sumatera Coffee succeeds as a commodity that must be taken into account. Most of the coffee land owned by the people should be able to improve the welfare of the people, but because it does not meet the Good Agriculture Practice (GAP) procedure, namely the application of agricultural production process system using environmentally friendly and sustainable technology, which to obtain good quality crops. From that description, should the economic benefits with tradition or empowerment Tunggu Tubang in the field of coffee plantation can provide welfare for families and villagers.

- As a result of higher education and marriage to people outside the region, changes in the marital context, which were initially prioritized to other ethnic marriages to safeguard ancestral assets. Then interethnic marriages also cause conflicts over family integrity, cultural differences, mindset, habits and perspective of life.Tunggu Tubang to abandon the role of those who essentially have to maintain old homes, and care for their parents and relatives. In addition, Tunggu Tubang no longer manages and preserve the environment (houses, rice fields, gardens, ponds, and customary forest).

- Homes, paddy fields, gardens, ponds and indigenous forest are abandoned and they pay wages to their nearest relatives or others to take care of them.

- Internal family conflicts resulting from the unfair distribution of rice and garden yields (some of Tunggu Tubang has already relinquish hed their roles and left homes and farm lands abandoned).

- There are some houses and land owned by Tunggu Tubang sold or in the exchange with the local community, and Tunggu Tubang with big family agreement to buy house and rice field that is outside their village for example in Palembang area. In the area of Palembang, Tunggu Tubang only has houses and rice fields that are not comparable with what they have at the time in thevillage.

- TungguTubang who are young and have jobs as teachers, lecturers, civil servants, and 
other jobs outside rural areas, they are not settled in oldhomes and have very little knowledge of environmental management and conservation.

- The role of customary institutions in the community as one of the alternative solutions for conflict/dispute in the midst of society is not functioning optimally, because the conflict of indigenous forest within the tradition area of Tunggu Tubang Semende community still can not becompleted.

\section{Conclusion}

Tunggu Tubang with the role as a farmer who cultivates rice fields and plantations to experience development and change. Changes in culture from the initial roles that are only tied to limited land, make the women of Tunggu Tubang experience a process of selfdevelopment due to their interaction in people's lives. The point of view determines the attitude of the knowledge gained so far even though it gets the value of appreciation for the status obtained in the Semende ethnic community. Changes in the role of the Tunggu Tubang are influenced by several factors, including the process of social and cultural change in the community which has a big influence on the implementation of the cultural values being interpreted. The values that have been inherited become the legitimacy of society towards culture. The transformation of the meaning of values leads to the existence of culture and cultural values. Tunggu Tubang as a symbol and meaning that is valuable, inherited from generation to generation has experienced developments and changes in the interpretation of the Tunggu Tubang actor. A sacred value rooted for the local wisdom of the environment and for kinship. The meaning of valuable value undergoes a shift to make the meaning worthless due to the low education of Tunggu Tubang and the inability to reflect on themselves due to the burden of women's lives on ulayat land. The balance of human life, culture, and nature that gave birth to the mindset for happiness and the wellbeing of life does not have to stop just like that. The challenges of the times to make the community should be wise in the environmental ethics that surround it. The local wisdom of TungguTubang is one of the many local wisdom of the Indonesian nation. The education and teaching of local wisdom culture on the management and preservation of the environment should continue to resonate to become a very valuable meaning for the nextgeneration.

\section{References}

1. Hans Daeng., Manusia, Kebudayaan, dan Lingkungan (Pustaka Pelajar, Yogyakarta, 2012)

2. R.C. Bogdan and S.K. Biklen, Qualitatitive Research for Education : An Introduction to Theory and Methods (Boston : allyn and Bacon, Inc, 1982)

3. John W. Creswell, Penelitian Kualitatif dan Desain Riset: Memilih Diantara Lima Pendekatan. ( Pustaka Pelajar, Yogyakarta, 2015)

4. H. M. Syahabuddin Zuhri and Amran Halim, Adat Tunggu Tubang Semende Dalam Persfektif Sejarah (Noer Fikry, Palembang, 2016)

5. Martin, Suharjito, Darusman, Sunito and Winarno. J. JMHT 22, 2 (2016)

6. R. Putra, Tradisi Parbiye Dalam Perkawinan Adat Semende Perspektif Masalah AlTufi, (Tesis, Pascasarjana Universitas Islam Negeri Maulana Malik Ibrahim, Malang, 2017) 
7. Eni Murdiati, Sriati, Alfitri and M.R. J. Eco. Env. \& Cons 24, 3 (2018)

8. Iskandar, Kedudukan Anak Tunggu Tubang Dalam Pewarisan Masyarakat Adat Suku Semende di Kota Palembang (Universitas Diponegoro, Semarang, 2003)

9. Soerjono Soekanto, Sosiologi Suatu Pengantar, (Rajawali Pers, Jakarta, 2012) 